\title{
BLOOD, SECT AND FEARS
}

\author{
WHY DO PEOPLE DONATE BLOOD TO STRANGERS? PROFESSOR \\ JACOB COPEMAN, A SOCIAL ANTHROPOLOGIST AT THE UNIVERSITY \\ OF SANTIAGO DE COMPOSTELA IN SPAIN, HAS DISCOVERED THAT \\ RELIGION, CULTURE AND POLITICS ALL PLAY THEIR PART
}

\section{TALK LIKE A SOCIAL ANTHROPOLOGIST}

RELIGIOUS GURU - a teacher or master of spiritual and religious knowledge

DEVOTEE - a strong believer in a religion who follows the teachings of a guru

If a member of your family was ill and needed blood, would you give up some of your own to save them? What if the person was not a family member, but a stranger? The idea of giving your own blood to somebody you have never met before might seem strange, but this is what millions of people around the world do every year.

Professor Jacob Copeman is a social anthropologist at the University of Santiago de Compostela in Spain. He has been trying to understand why people are motivated to donate their blood, and how this fits into the fabric of our societies. He has discovered that there is far more to donating than medical facts. Giving blood is also about politics, religion and social influencers.
WHAT IS VOLUNTARY BLOOD

\section{DONATION?}

There are some medical conditions such as anaemia and leukaemia that affect the health of a person's blood. These can be treated by giving the patient healthy blood from someone else and injecting it into a blood vessel. This process is known as a blood transfusion, and it is also used to help people who have lost blood during surgery, childbirth or an accident. Blood transfusions save millions of lives around the world, but they would be impossible without blood donations.

Voluntary blood donation is where somebody gives their blood to be used by whoever might need it, without getting any payment in return. Alternatively, a donor might give their blood to a central blood bank because they have a relative who needs a blood transfusion. This is known as a replacement donation. A third type of donation is a commercial one, where the donor receives a payment. However, voluntary donation is considered the safest method for patients, and is strongly encouraged by the World Health Organization (WHO).
WHAT HAS BLOOD DONATION GOT TO DO WITH ANTHROPOLOGY?

In your biology classes you will have learned that blood is a bodily fluid made up of plasma, red blood cells, white blood cells and platelets. But is this the first thing that comes to mind when you hear the word blood? Depending on your beliefs and culture, you might associate blood with family connections, Christ on the cross, halal meat, war, sacrifice, or any number of other things. Blood donation, therefore, means different things to different people, and this is what anthropologists such as Jacob are interested in.

Jacob has covered attitudes towards blood donation around the world, in countries that include Brazil, China, India, the Navajo Nation, Papua New Guinea, Sri Lanka and the United States. He says it is an "extraordinary emotive force for some communities, and often the source of controversies". Jacob has looked at how non-governmental organisations (NGOs) teach the science of blood regeneration to help allay people's fears about donating, how blood banks work, how people link blood donation to ancient Indian ideas of gift-giving, 



\section{O ABOUT SOCIAL ANTHROPOLOGY}

How do social structures and practices differ, and how are they the same? What defines culture, and what is universally human? These are the questions that anthropologists try to answer. They do so by studying peoples' lives in detail, often by living alongside communities for extended periods of time.

DO ANTHROPOLOGISTS STUDY REMOTE TRIBES?

Social anthropology is often associated with the study of small, isolated communities. While this is sometimes the case, anthropologists are interested in much more. Ultimately, any community, from any part of the world, has its own unique features and could be the subject of anthropological research.

WHY IS SOCIAL ANTHROPOLOGY IMPORTANT IN MEDICINE?

Advances in medicine are useless unless they are accepted by a society. The last time you swallowed a pill, did you stop to check the ingredients and find out how it works? Probably not, because you trust the pharmacy or doctor who gave you the pill. Building that trust between medicine and society is vital, and that is where anthropology can help.

Medical anthropologists explore belief systems, power structures and motivations in different medical contexts. This can help the medical profession to communicate effectively with different populations. Jacob's work on blood donation in India is just one example of this type of anthropology.

\section{EXPLORE A CAREER IN SOCIAL ANTHROPOLOGY}

- Anthropology is global in its reach, and gives you the tools to research the nature of societies, communities and organisations. Learn more about the subject at

www.discoveranthropology.org.uk.

- The American Anthropology Association has a YouTube playlist showcasing anthropologists in a wide range of specialities:

www.youtube.com/playlist?list=PLOOchIJ85m4f_2--kdkxQIt9ozy9CQc2K

- You could work in academia, policy, development, social work, business and in many other sectors. Salaries for academic anthropologists in the UK range from $£ 32,000$ to $£ 82,000$.

\section{JACOB'S TOP TIPS}

OI Develop your curiosity for how different cultures, organisations and societies work. Read newspapers, follow relevant media channels, watch relevant TV programmes. Be curious

when travelling, both in your home country and abroad.

02 Only a small number of social anthropologists follow an academic career. Explore other sectors where your degree will be valuable, including education, human resources (HR), public relations (PR), social work, museum work, charity and international development, policy work, market research, film or business. Gain practical experience during your studies to help you decide which sectors interest you most.

03 Remember that many people will not fully understand what social anthropology is about, and you may need to explain it concisely to future employers. Be ready to talk about the valuable skillset you will develop through your studies.

\section{PATHWAY FROM SCHOOL TO SOCIAL ANTHROPOLOGY}

- To study anthropology at university, you will need to show an interest in how different societies work, and the people who make up these different societies.

- English literature, religious studies and history will all stand you in good stead as an anthropologist. However, most universities do not require specific subjects.

- Some anthropologists come to the field after studying another arts or humanities subjects. Jacob, for example, studied English for his first degree.

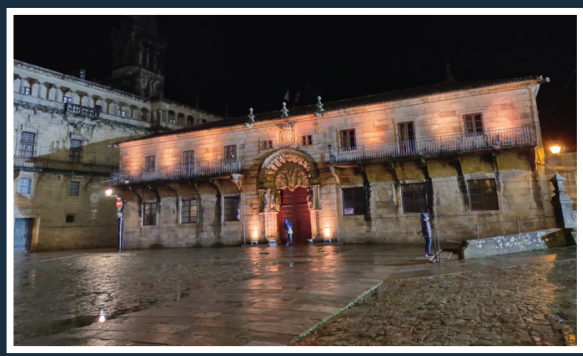

A photo taken by Jacob of the University of Santiago de Compostela at night. Imagine this being your place of work! 
